Article

\title{
A Scoping Review of Barriers to Investment in Climate Change Solutions
}

\author{
Sarah Hafner, Olivia James and Aled Jones * \\ Global Sustainability Institute, Anglia Ruskin University, East Road, Cambridge CB1 1PT, UK; \\ Sarah.Hafner@anglia.ac.uk (S.H.); oliviajames15@yahoo.co.uk (O.J.) \\ * Correspondence: aled.jones@anglia.ac.uk
}

Received: 26 April 2019; Accepted: 4 June 2019; Published: 8 June 2019

check for updates

\begin{abstract}
The finance sector has engaged with policy development processes associated with climate solutions for well over a decade, with the aim of overcoming barriers to investment. In this paper we analyse 31 practice-based policy reports which highlight key barriers to such investing. We use those practice-based policy reports to identify themes associated with barriers to investment to conduct a scoping literature review of academic research. We identify 91 relevant papers and use content analysis to summarise the barriers identified in a structured way to help inform the research landscape in a timely manner. Given the urgency of this issue, we call on the academic community to focus more effort in this new and emerging discipline and, in particular, on the need for an independent view on the validity of some of the claims made in these practice-based policy reports.
\end{abstract}

Keywords: renewable energy investment; policy uncertainty; long term investment; private sector short termism

\section{Introduction}

This paper presents a scoping review of 91 academic papers to explore the barriers to investment in renewable energy infrastructure. The scoping review uses content analysis as derived from a set of 31 practice-based reports, published after the United Nations 15th Conference of the Parties (COP15) in Copenhagen in 2009, by leading networks, groups, or think tanks that represent the investment community. The key barriers identified are the short-term nature of investors, policy uncertainty, and the lack of appropriate scale in investment opportunities. These may be linked to the immaturity of the market; however, it also highlights that there is a need for better communication between the three communities-policy, academia and investors-to prioritise research activity so that lessons can be learnt and acted upon quickly. We find there is an important disconnect between academic research and those practice-based reports and, in particular, areas of identified barriers by the investment community, such as technology risk, benchmarking, market liquidity, fossil fuel subsidies, fiduciary duty, and credit rating, are less well covered in the academic literature.

For well over a decade calls for a significant change in investment decision making to enable a transition to a low carbon clean energy system have been made [1,2]. Estimates prior to COP15 put forth an annual investment need of approximately $\$ 500$ billion [1]. A number of private and public sector investment groups had focused attention on the potential for a significant global agreement to emerge from COP15. However, the Copenhagen summit failed to deliver on investor expectations [2]. Although there has been some progress since COP15, there remains a gap in investment and, therefore, a need to better capture, and respond to, barriers to scaling up this investment.

Calls for a significant increase in investment into green and renewable infrastructure have been increasing [3] and have been matched by calls from the private sector for better alignment of underlying policy and regulation, at both national and international levels [4-6], that would underpin this growth. 
A significant focus for these discussions at the international level has been on mobilising capital flows from developed to developing countries [7]. However, there is little in the way of effective policy and regulatory frameworks in developed countries themselves [8].

Having said that, the total investment in renewable energy infrastructure grew by $16 \%$, to almost $\$ 280$ billion, in 2017 [9], with investments in solar power alone being larger than those investments into fossil fuels. This is still far below what is required $[8,10]$ and, therefore, despite this increase in investment, which has been driven in part by lower technology deployment costs and policy instruments, there is still a need for focused action on climate finance.

Whilst investing into developing and emerging economies always has additional risks regardless of the particular asset that is being invested into, there is currently no unambiguous agreement as to why there is not sufficient capital flowing into sustainable investments in developed countries [11]. However, it is acknowledged that there remains significant market and policy/regulatory distortion and other important barriers (such as short-terminism, missing financial instruments, missing information on the risk of climate change, missing data to rank sustainable investments, etc.), even in these mature economies $[5,12,13]$.

While the investment community now regularly engages with policy consultation processes, workshops, and academic research [14-16], including with the European Union, national governments and central banks, there is a gap between calls for action and changes in regulation or policy. Therefore, there is a need for a better capturing of this emerging knowledge, testing of proposed solutions, and modelling of potential outcomes.

We acknowledge that there may be several barriers to academics engaging in this research space, including a lack of engagement by leading finance or business journals, a lack of funding for this type of research, or, indeed, a lack of available data for analysis [17]. However, there is also increasing evidence of engagement by the academic community, including conferences with a specific focus on climate finance or, indeed, special issues of journals [11].

Given this background, this paper tackles the research question of how widely the investigation of particular barriers to investing in climate change solutions is covered within the current academic literature. Specifically, it tries to summarise academic literature that explores particular barriers identified by the practice community (investors), as documented in policy reports. These barriers are those identified that relate to the mobilising of capital into green/climate finance investment opportunities in a developed country context. We define a developed country here as those countries not eligible for overseas development aid. A developed country context has been chosen as it is viewed that these markets are currently more sophisticated in their general approach to financial and energy policy and, therefore, barriers identified will be more specific to technology deployment, as opposed to general barriers associated with investing in countries with a low credit risk rating. In addition, developed countries, in this context, do not qualify for international climate finance development aid through programmes such as the World Bank, which may impact on the assessment of the underlying projects. In this paper, we define climate change solutions as limited to energy infrastructure, which provide the potential for climate change mitigation over a business as usual scenario. Therefore, this is predominantly related to renewable energy infrastructure investment.

\section{Materials and Methods}

A scoping review was chosen to explore the current literature as this "represents a methodology that allows assessment of emerging evidence, as well as a first step in research development" [18]. In particular, we note that as this is an emerging area of research with limited engagement with the leading finance or business journals [17], a scoping review is appropriate at this time. The steps undertaken in the methodology included the following:

1. Identification of practice-based policy reports;

2. Identification of key themes and keywords/codes; 
3. Scoping review (ex-post) of policy reports using barrier code words found in the first round of coding;

4. Use of barrier code words in a content analysis of academic literature.

\subsection{Criteria for Selection of Practice-Based Policy Reports}

This study is restricted to those practice-based reports that have been published after the meeting of the Conference of the Parties in Copenhagen in 2009. Reports needed to either mention barriers to investment or propose solutions such that barriers could be identified.

Given the focus is on mobilising private sector capital in developed countries, the study is also restricted to those groups from that region or reports that discuss or target developed country investment. No further geographic restriction is applied and the reports cover Australasia, Europe, or North America in the main. Additionally, the aim of this study is to capture wider barriers to investment, as opposed to specific issues within individual firms and, therefore, the reports were further restricted to those that purport to represent industry views-either by virtue of being endorsed or published by multi-stakeholder groups or by virtue of being based on consultations with multiple parties.

Therefore, the criteria for inclusion of practice-based investment reports is as follows:

- $\quad$ Published since 2009;

- Published by organisations in developed countries;

- Include specific reference to barriers or solutions in large-scale clean energy infrastructure investment;

- Published by multi-stakeholder groups, or an organisation, either public or private, that regularly consults multiple parties across the investment community.

A Google search was performed using the criteria as specified above. A set of key words were used including (investment), AND (energy, OR renewable, OR green) AND (barrier OR solution). Paid for advertised reports were discounted and the first 5 pages of Google results were searched. For some organisations, multiple reports have been published that outline very similar concepts (for example, the Climate Policy Initiative has published numerous reports in this field) and so, after a review of these, one or two documents that covered the key issues in the other reports were chosen. One exception was made to the criteria as outlined above, which was the publication by the International Energy Agency [1] as this report is often referenced by others, is seen as a document that captures subsequent International Energy Agency report positions, and is seen as a clear collation of barriers to investment prior to the Copenhagen meeting. We note that a Google search for grey literature is limited and, therefore, cannot confirm that all relevant grey literature has been included. We also note the limitations of a Google search, as this is not easily reproducible by others; however, we provide as much detail as we can.

Table 1 summarises the 31 reports included in this review. This list was an attempt to be as comprehensive as possible with regard to capturing all relevant barriers of climate finance. However, while we acknowledge there are practice-based reports not included here, and this may introduce some bias in our analysis, we are confident that all key barriers described within them are covered. 
Table 1. Practice-based reports included in the review (alphabetical order).

\begin{tabular}{|c|c|c|}
\hline Author/Organisation & Year of Publication & Title \\
\hline Aldersgate Group & $2018[4]$ & $\begin{array}{l}\text { Towards the new normal: How to increase investments in the UK's } \\
\text { green infrastructure? }\end{array}$ \\
\hline British Banking Association & 2015 [19] & Financing the UK's infrastructure needs \\
\hline Climate Policy Initiative & $2013[3]$ & The challenge of Institutional Investment in Renewable Energy \\
\hline E3G & $2016[20]$ & A Sustainable Finance Plan for the European Union \\
\hline $\begin{array}{l}\text { EU High Level Expert Group on } \\
\text { Sustainable Finance }\end{array}$ & $2018[21]$ & Financing a Sustainable European Economy \\
\hline European Commission & 2017 [22] & $\begin{array}{l}\text { Financing Sustainability. Triggering Investments for the } \\
\text { Clean Economy }\end{array}$ \\
\hline EY & 2016 [6] & Climate change. The investment perspective \\
\hline G20 & 2016 [13] & G20 Green Finance Synthesis Report \\
\hline Green Finance Initiative & $2017[23]$ & $\begin{array}{l}\text { The Renewable Energy Infrastructure Investment Opportunity for } \\
\text { UK Pension Funds }\end{array}$ \\
\hline & $2017[24]$ & Fifteen Steps to Green Finance \\
\hline Green Finance Taskforce & 2018 [25] & Accelerating Green Finance \\
\hline $\begin{array}{l}\text { Green Investment Bank } \\
\text { Commission }\end{array}$ & 2010 [12] & Unlocking investment to deliver Britain's low carbon future \\
\hline GREEN-WIN & $2017[10]$ & $\begin{array}{l}\text { Financing the Low-Carbon Transition: Current Landscape and } \\
\text { Future Direction }\end{array}$ \\
\hline IFC & $2013[26]$ & $\begin{array}{l}\text { Mobilizing Public and Private Funds for Inclusive Green Growth } \\
\text { Investment in Developing Countries }\end{array}$ \\
\hline IIGCC, INCR, IGCC and UNEP-FI & $2011[2]$ & $\begin{array}{l}\text { Investment-grade climate change policy: Financing the transition to } \\
\text { the low-carbon economy }\end{array}$ \\
\hline $\begin{array}{l}\text { Institutional Investors Group on } \\
\text { Climate Change }\end{array}$ & $2015[5]$ & $\begin{array}{l}\text { Achieving the Investment Plan for Europe’s } £ 315 \text { billion ambition: } \\
\qquad 12 \text { fixes }\end{array}$ \\
\hline $\begin{array}{l}\text { International Centre for Trade and } \\
\text { Sustainable Development }\end{array}$ & 2015 [27] & Breaking down the barriers to clean energy trade and investment \\
\hline International Energy Agency & 2007 [1] & Climate Policy Uncertainty and Investment Risk \\
\hline IRENA & $2016[28]$ & $\begin{array}{l}\text { Unlocking Renewable Energy Investment: The Role of Risk } \\
\text { Mitigation and Structured Finance }\end{array}$ \\
\hline Mercer & 2015 [29] & Investing in a time of climate change \\
\hline \multirow{8}{*}{$\begin{array}{c}\text { Organisation for Economic } \\
\text { Co-operation and Development } \\
\text { (OECD) }\end{array}$} & $2011[30]$ & The Role of Pension Funds in Financing Green Growth Initiatives \\
\hline & $2012[31]$ & $\begin{array}{l}\text { Towards a Green Investment Policy Framework: The Case of } \\
\text { Low-Carbon, Climate-Resilient Infrastructure }\end{array}$ \\
\hline & 2013 [32] & Long-term investors and green infrastructure \\
\hline & 2013 [33] & Institutional Investors and Green Infrastructure Investments \\
\hline & $2014[34]$ & $\begin{array}{l}\text { Public Financial Institutions and the Low-carbon Transitions: Five } \\
\text { Case Studies on Low-carbon infrastructure and project investment }\end{array}$ \\
\hline & 2015 [35] & Mobilising private investment in clean-energy infrastructure \\
\hline & 2015 [36] & Overcoming Barriers to International Investment in Clean Energy \\
\hline & 2016 [37] & $\begin{array}{l}\text { Progress Report on Approaches to Mobilising Institutional } \\
\text { Investment for Green Infrastructure }\end{array}$ \\
\hline UNEP & $2015[38]$ & $\begin{array}{l}\text { The financial System We Need: Aligning Financial System with } \\
\text { Sustainable development }\end{array}$ \\
\hline Vivid Economics & 2014 [8] & Financing Green Growth \\
\hline World Bank & 2012 [7] & Green Infrastructure Finance \\
\hline
\end{tabular}

\subsection{Coding of Policy Report}

Each of the reports in Table 1 were read initially to get an overview of the landscape as set out by their contents. Subsequently, the reports were analysed and key sentences were highlighted where barriers or solutions were identified. These sentences were then coded [39] to identify a set of common themes and code words. 
Themes were used to ease the process of identifying particular code words or phrases. In particular, the language used in each report is not consistent and, partially, has evolved over time. Therefore, themes were used to bring together similar issues to allow a smaller set of consistent code words to emerge. During this process, particular code words were identified that may not have been present in the original documents in their precise form. However, for the scoping review of the policy-reports, a specific sub-topic is only reported in our table if the exact keyword/code has been found in the report. We note that some of these themes may overlap and some code words could be used against multiple themes (such as 'risk return'). In the discussion of the content of the papers presented in the paper, this overlap is taken into consideration as the code words were used independently of the themes during the scoping review and all papers were analysed together so any overlap was identified and papers could inform multiple themes, if appropriate.

\subsection{Scoping Review of Academic Literature}

A scoping review was used $[18,40]$, which includes identification of a suitable database for searching, the use of code words to focus the search, and a two-step process for assessing identified papers. The titles, full author list, and abstracts for the papers identified were downloaded into a spreadsheet by O.J. (the second author of this paper). The first step of assessing identified papers involves one researcher (O.J.) adopting a content analysis approach [41,42] to the database using the code words to identify a full set of papers and then conducting a first pass of reading the papers to narrow these down to those that are relevant. We adopted a simple scale for this first step of content analysis [41], using a ' 2 ' for papers that were deemed relevant, a ' 1 ' for those that may be relevant, and ' 0 ' for those that were not. The second step involved the other researchers (S.H. and A.J., first and third authors) independently cross checking this initial assessment of papers to identify a final set of papers for analysis and assigning either a ' 2 ' for those relevant to a particular code word and a ' 0 ' for those not relevant. Any disagreements of identified papers were discussed between S.H. and A.J. before a final decision was taken, although this only occurred for a small number of papers.

The code words or phrases identified were used for a search using the ISI Web-of-Knowledge (apps.webofknowledge.com) Core Collection online database. All types of article were included and their titles, abstracts and keywords were searched from the full database. No date restriction was used, so all papers published prior to the search (July 2018) were included. We note that published working papers or the like are unlikely to be included on this database until they are published in a peer reviewed journal. Of course, the research reflected in this search is likely to be out of date by the period of time it takes to write, submit, revise, and publish academic papers and, therefore, is likely to reflect active research up until 2017 at the latest.

Only titles, abstracts, and keywords were searched, given the limitations of the Web-of-Knowledge search engine. However, as this paper intends to identify academic output where the focus is on understanding these barriers, this was deemed sufficient for this initial scoping review. It is acknowledged that some research where the identification of particular barriers is peripheral to the core work may have been missed and in the future it would be useful to expand the search to the full text of the papers, to other search engines, or by the use of further key words, although this goes beyond the scope of this paper.

To restrict the search to those papers that explored barriers within the context of green investment, the following topic search was used:

$$
T S=((\text { investment AND energy AND (renewable OR green)) AND ("one of the code words"”)). }
$$

The initial code word search of the Web-of-Knowledge produced 2395 papers. Note that some papers may appear multiple times against different code words and, therefore, this does not necessarily represent 2395 unique papers. After checking the relevance of the titles of each, producing a shortlist, 
and then downloading the abstracts and cross-checking the relevance, a total of 91 relevant papers were found. Of these 72 were articles, 11 reviews, 6 proceedings, 3 book chapters, and 2 editorials.

It is of course important to note that the identified papers in this review are limited by the search terms used. We aimed to be as exhaustive as possible without opening up the search terms to make exploring the database unmanageable and restricted these terms to similar phrasing, as used in the policy documents. However, we do note that some issues may have been missed in this way and we recommend that further more detailed searches around particular themes/code words may be needed to expand our findings in future research. For example, the issue of fiduciary duty only came up in one of our papers [43], but it is explored in more detail in a related research field-that of Socially Responsible Investment (SRI) [44,45].

\section{Results}

There were 11 themes identified and 35 code words (or phrases) from the analysis of the practice-based reports. Table 2 presents the themes and code words used. In addition, the code word 'Barrier' was used to ensure all relevant academic papers were captured that specifically addressed barriers to investment.

Table 2. Themes and code words identified through the analysis of the practice policy reports.

\begin{tabular}{|c|c|}
\hline Theme & Code Words \\
\hline $\begin{array}{l}\text { Immaturity of climate change policy frameworks and } \\
\text { lack of stable policies }\end{array}$ & $\begin{array}{l}\text { Policy framework; Policy direction; Long term; Policy } \\
\text { uncertainty; Stable regulatory framework; Policy } \\
\text { stability; Certainty }\end{array}$ \\
\hline $\begin{array}{l}\text { Policies are in favour of 'brown' energy-infrastructure } \\
\text { (e.g., fossil fuel subsidies) }\end{array}$ & $\begin{array}{l}\text { Fossil fuel subsidies; Carbon price; Perverse } \\
\text { incentives; Distorted }\end{array}$ \\
\hline $\begin{array}{c}\text { Constraints on decision making within investor } \\
\text { companies }\end{array}$ & $\begin{array}{l}\text { Fiduciary duty; Trust; Investor perceptions; } \\
\text { Awareness; Short term; Accounting; Solvency }\end{array}$ \\
\hline $\begin{array}{c}\text { Perceptions that returns of renewable infrastructure } \\
\text { investments are too low and require high initial } \\
\text { capital investment }\end{array}$ & Risk return \\
\hline $\begin{array}{l}\text { Requirement that projects need a certain credit rating } \\
\text { so that it is possible to invest }\end{array}$ & Credit rating; Risk rating; Credit worthy \\
\hline $\begin{array}{c}\text { Technology-risk associated with uncertain and } \\
\text { unproved technologies }\end{array}$ & Technology risk \\
\hline Transparency on climate related disclosure and data & Climate disclosure; Standards; ESG; Benchmark \\
\hline Limited projects with acceptable risk-return profiles & Liquidity; Liquid market; Scale \\
\hline $\begin{array}{l}\text { Lack of suitable financial vehicles/financial } \\
\text { instruments }\end{array}$ & Financial vehicle; Financial instruments \\
\hline High transaction costs or fees & Transaction costs; High fees \\
\hline $\begin{array}{c}\text { Lack of knowledge/technical advice on green } \\
\text { infrastructure investment }\end{array}$ & Technical advice; Technical knowledge \\
\hline Other barriers & Barrier \\
\hline
\end{tabular}

The most popular journals for publishing are Energy Policy, with 21 papers, and Renewable and Sustainable Energy Reviews, with 9 papers. Five papers were published prior to 2009; however, the vast majority were published after 2009 (Figure 1). As can be seen in Figure 1, the number of papers published each year has increased from 2009 until 2017. In 2018, up until the end of July 2018, there were 12 papers published (not shown) and, therefore, with 5 months still left it is likely that the 2017 total will be exceeded, so the trend of increasing publications will continue. There was an increase in 2010, which could reflect a focus of research immediately post the Copenhagen summit in 2009 (given 
that academic papers usually appear 1 to 2 years after the research has been conducted). However, the numbers are low, so no definitive conclusion can be drawn.

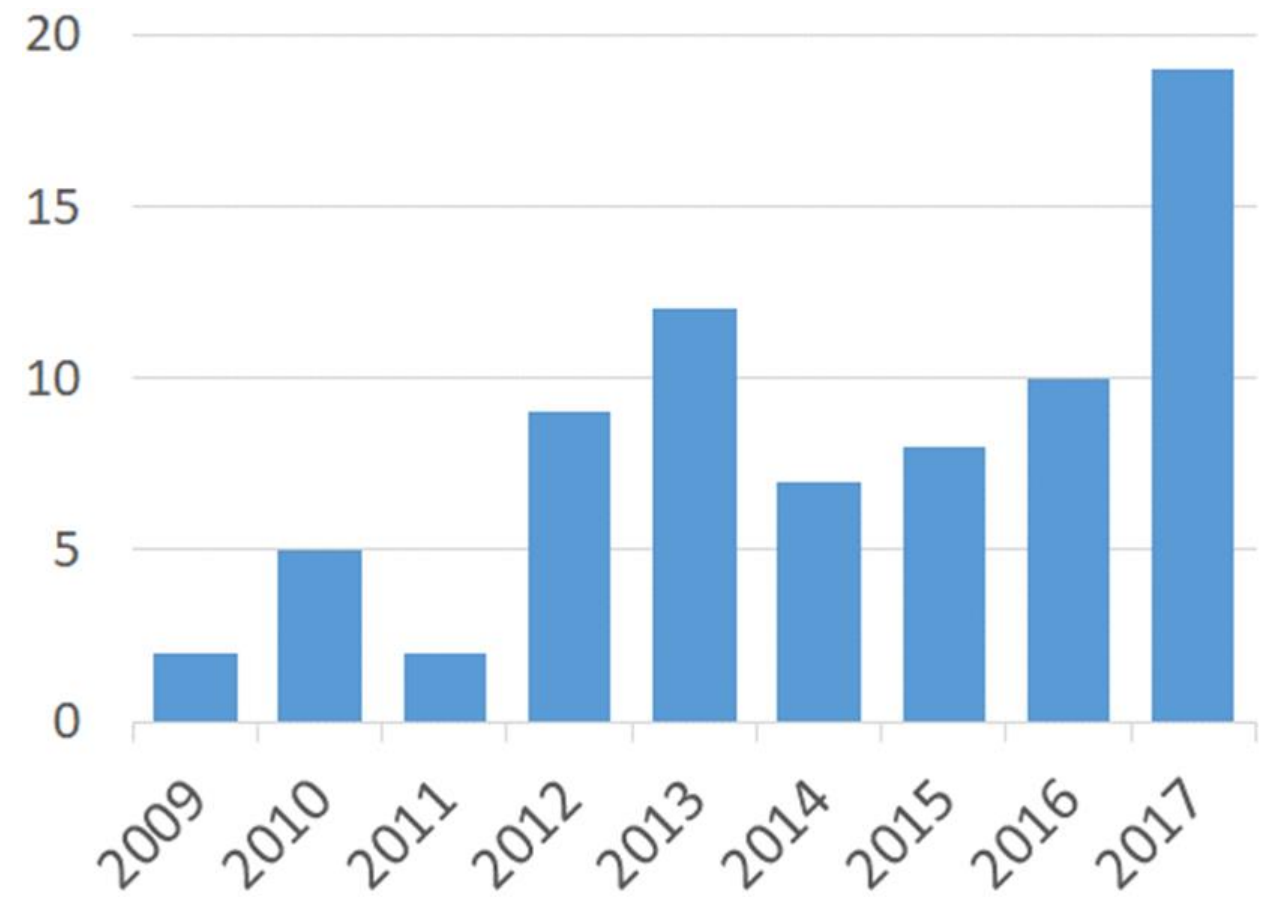

Figure 1. Number of papers published each year, including in the final papers analysed between 2009 and 2017.

The papers were not generally clustered in any particular country with the following representing the top 6 countries for the author base: Germany (15), USA (15), UK (12), Netherlands (9), Switzerland (8), and China (7). However, the Research Council of Norway (5 papers) and the European Union (4 papers) were the two most acknowledged sources of funding.

The code words were generally much more common in the practice-based policy reports as compared to the academic papers. Figure 2 shows the number of times each code words appeared in the search of academic papers compared to the number of times they appeared in the policy reports. For example, the dot in the top right-hand side of the figure is the code word 'Barriers' which appeared in 34 of the 91 academic papers and 28 of the 31 policy reports. The other two most common code words were 'Long term' (appearing in 22 academic papers and 17 policy reports) and 'Scale' (appearing in 15 academic papers and 18 policy reports). The next most common terms in academic literature were 'Policy uncertainty' (appearing 9 times) and 'Short term' (appearing 11 times).

When examined by theme, it is clear that some barriers are better covered than others. For example, the general barrier associated with the immaturity of policy is strongly covered in both policy and academic papers, with an average of 8 policy reports found for each code word and 6 academic papers. However, there are key emerging themes in the policy reports which are not at all well covered in academic literature, but that feature strongly in the policy reports. This includes the requirements of credit ratings, technology risk, lack of appropriate financial vehicles, and high transaction costs. These issues all relate to the creation of a deal flow and pipeline of projects and, therefore, the lack of literature may be indicative of a forward look by investor groups or policy makers against a lack of data or evidence for academic exploration, which would be consistent with previous findings [15]. It may also be due to a lack of consistency in the use of those specific terms between the academic and practice-based communities.

Each paper is cited, on average, 14.16 times with a total of 1289 cites. To date there have been 232 citations in 2018 and a growing trend in citations per year (see Figure 3). The most cited papers 
are Wuestenhagen and Menichetti [11] and Klessmann, Held, and Rathmann [46] both with 104 cites. Wuestenhagen and Menichetti [11] is an overview paper for a special issue of Energy Policy that brings together papers presented at a conference in Switzerland in 2010 under the title Strategic Choices for Renewable Energy Investment. However, note that only one other paper from that special issue [47] has been picked up by the searches. Klessmann, Held, and Rathmann [46] is an evaluation of renewable energy system deployment across the European Union to explore what was needed to meet the 2020 targets. The next five highly cited papers are more specific case studies on Sweden [48] (with 81 cites), solar photovoltaics in the European Union [49] (with 62 cites), microgrids [50] (with 61 cites), wind power [51] (with 61 cites), and feed-in-tariffs in Canada [52] (with 51 cites).

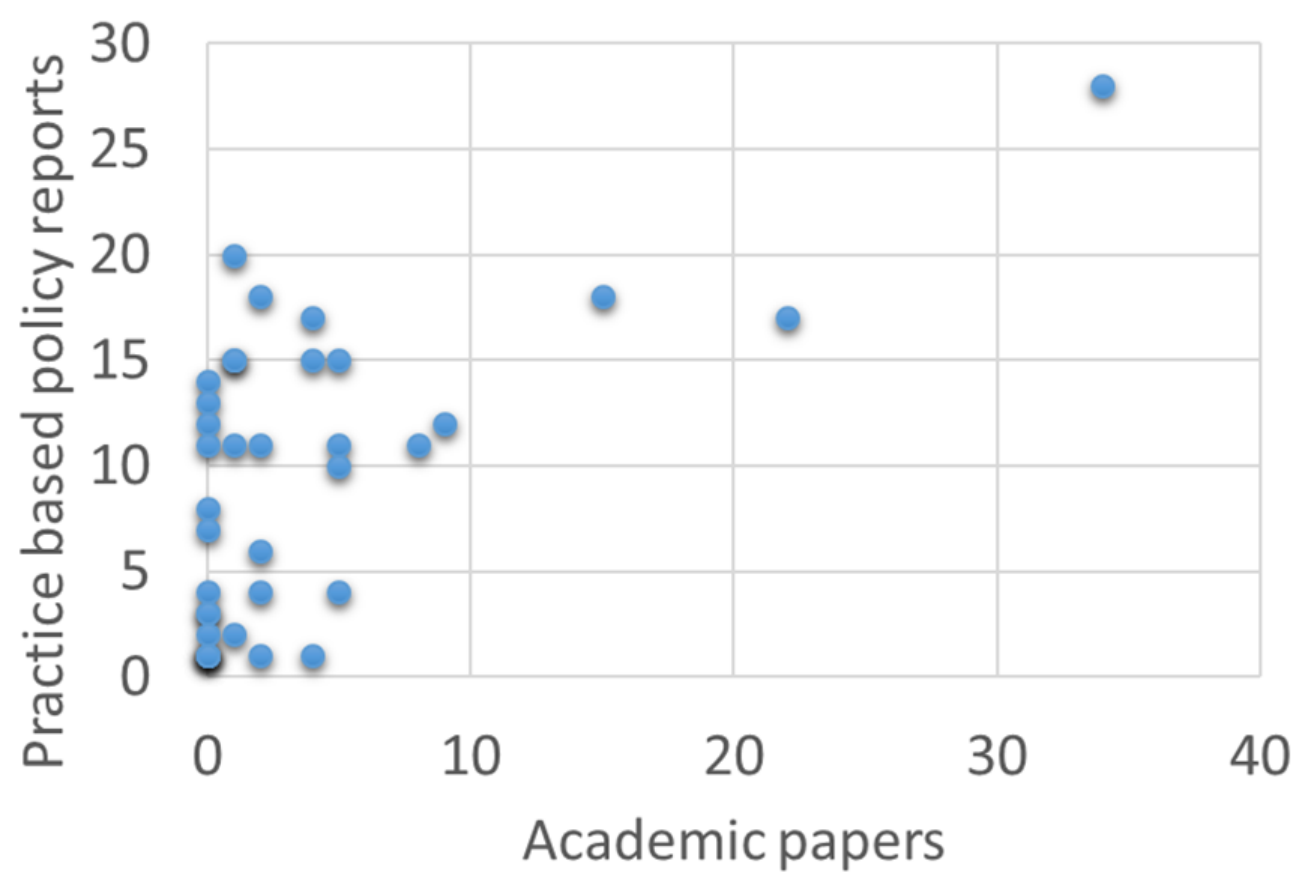

Figure 2. Code word prevalence in the policy reports compared to the academic papers.

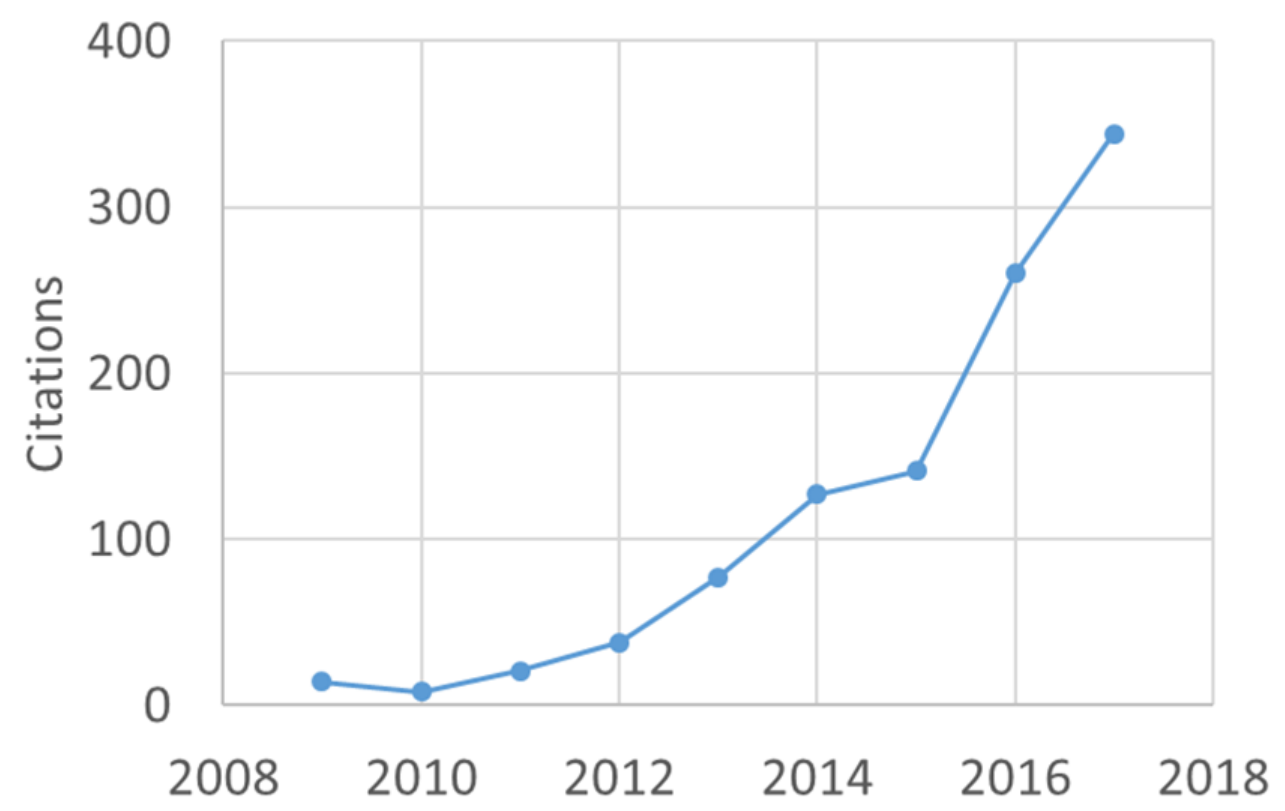

Figure 3. Number of citations per year for the academic papers. 


\section{Discussion}

Whilst exploring in detail the barriers to investment in climate change solutions, there is a range of different approaches adopted in the academic literature. In general, we find that there are indeed many barriers, although the extent to which these barriers are the focus of study themselves varies greatly. The barriers are often identified as those specific to a particular technology deployment, country, or within the context of an economy that has a path dependency associated with fossil fuels. Indeed, if all economic regulation and the future strategy of economic growth was aligned with finding a solution to climate change then the majority of the barriers would not exist [53-55]. Of course, as investment into climate change solutions increases, then new risks and technology 'lock-in' may occur, depending on how specific policy is implemented, which should be properly understood and measured [56,57].

\subsection{Identification of Investment Barriers}

While most of the reviewed studies investigated only one barrier-theme (as defined in this study), a small number of papers took a broad approach to try and identify the full set of barriers to investment through literature reviews and/or interviews with experts. Through 14 interviews with experts, one study [43] identified cost barriers, communication barriers, fiduciary duty barriers, and poor communication from government over policy as the most prevalent (note these specific barriers did not appear in the title, abstract, or keywords and were therefore not reflected in the tables in Section 3). Gatzert and Kosub [58,59], using a non-systematic literature review of both academic and practitioner papers, found technical knowledge, technology risk, complex policy landscape, crediting worthiness of counter parties, and policy uncertainty or stability as key barriers to investment.

Taking a life cycle view of renewable infrastructure, one study [60], through a non-systematic academic literature review, identified different barriers at each stage of development. This includes the need for long term policy stability, institutional barriers (related to policies in favour of fossil fuels), and general economic or financial barriers (such as requiring subsidies) for less mature technologies, while planning and administrative approval and public acceptance were more important for more mature technologies. Exploring the integration of renewables into the European electricity market in more detail, Hu et al. [61], through a snowball literature review, find a range of barriers, including path dependence (fossil fuel dominance in the existing market), lack of knowledge, transaction costs, public acceptance, and accountancy practice (notably, discounting of future asset values).

One paper found the main barriers as a "lack of a mature community of investors, mismatches between investment and fund manager timescales, and lack of suitable investment vehicles" alongside structural barriers of "skill-base; long-term-nature of investments" [62]. They proposed that the lack of appropriate solutions to these barriers was due to the theoretical frameworks used to analyse and therefore a new theoretical framework called 'adaptive market hypothesis' was needed as a better perspective to analyse energy finance and develop solutions to these barriers [62].

Interestingly, one paper [63] also identified a number of technological, economic, social, or public barriers which overlap well with the barriers identified in the policy reports and the other papers identified. However, at least in the case of wind power in Saskatchewan, Canada, these barriers could be 'explained in large part by knowledge barriers' [63], as opposed to being real barriers. They stress that understanding the underlying source of the barrier is needed before solutions are proposed and implemented, although it could also be argued that solutions to perceived barriers may also tackle the perception of a barrier even if that barrier is not real.

\subsection{Theme Analysis}

Fifty-five papers were identified as exploring a specific set of barriers to investment in climate change solutions as defined in this paper as opposed to identifying a broad set of barriers (as the papers in the previous section did) or proposing solutions to presumed barriers (as the papers in the next section do). The following explores each of the themes (as defined in Table 2). 
Almost half of these 55 papers identified policy stability or uncertainty as a key barrier (for example, see [64]). Evidence of the importance of policy stability is already found through data linked to changing policy environments, including the production tax credit in the United States [51], public sector investment from the Australia Renewable Energy Agency [65], on-shore wind regulation across Europe [48,66-69], and solar feed-in-tariffs [52,70]. The termination of policy, especially when retroactively done, is often singled out when discussing policy stability/uncertainty [71,72]. Ensuring policy is designed to be as efficient and effective as possible is key so as to avoid over-subsidising technologies which, in turn, leads to higher costs for government and, therefore, an increase in the likelihood of changes in policy [73]. However, one paper has argued that policy uncertainty could, in fact, be beneficial to investments [74] as it 'provides higher expected consumer surplus and lower expected electricity price'.

When policy is implemented, the accountability around enforcement also needs to be clear or the lack of proper governance is often seen as a barrier $[75,76]$. For example, uncertainty in the renewable energy target in Australia [65,77] has seen several projects stall [78]. The issue of transparency and disclosure is highlighted as critical when attempting to demonstrate additionality in investments that attract carbon credits or benefit from other policies associated with greenhouse gas emission reductions [79]. Transparency, disclosure, and enforcement are of course linked through a strong governance environment.

While the lack of a global price on carbon has become less of a factor in the policy reports (partly due to the failure to deliver a global price on carbon under successive climate change agreements), the uncertainty around future carbon prices and policies that deliver a carbon price still feature in the academic literature [80,81].

The lack of long-term policy stability is particularly linked to the longer timescales of returns for a renewable infrastructure asset [82-84]. Indeed, when individual retail customers are a key source of investment, they often seek long term investments and then rely more on their 'gut feeling' to judge the risk associated with those investments [85]. However, the lack of policies to encourage investment for some climate change solutions [86-89] or an overly complex policy environment $[66,90]$ is potentially more of a barrier than policy uncertainty.

The causes of policy risk are also explored [90] and identified as economic stress, public acceptance of high costs (associated with providing subsidies), changes in the ideological approaches of government, and the autonomy of regulatory agencies. In addition, the pressure to change policy as the market for particular technologies mature and their costs lower was also highlighted [91]. Even if policy uncertainty were to reduce in particular countries, different countries implement different policies [92], so investment strategies are more difficult to develop globally.

While the issue of existing policies being in favour of fossil fuels [65] was not explicitly discussed in some papers the path dependency $[11,88,93,94]$ of the economy was often mentioned as a key barrier. A potential contributing factor to this barrier was highlighted as the strength of existing corporate, monopoly, or special interest lobbies and the vested interest of such groups, which, in some cases, could see investment into climate solutions redistributed to compensate for a shift of investment away from these assets [88,93].

The legal requirements on certain investors (such as the financial regulations Basel on banks or Solvency on insurers) can make investments more expensive in renewables [95]. In addition, the use of traditional accountancy methods in evaluating investments may favour conventional energy over high capital cost renewable technologies, especially when combined with biased perceptions within the investor community of higher risks associated with new innovation [96]. However, the general lack of awareness of certain technology solutions $[86,97]$ or a lack of expertise or track record in designing new financial vehicles $[80,88]$ within the investment community is also seen as a barrier. Linked to this general awareness is often a lack of trust between investors, policy makers, and technology developers [98] that would only improve as the market matures. 
Higher up-front capital requirements $[50,87,97,99]$, when compared to traditional energy assets, represent a specific barrier for renewable energy infrastructure. High initial costs often include an expectation of higher returns over the lifetime of the investment to compensate for the additional risk that this initial investment represents $[11,86,88,100]$. Indeed, the question of whether a renewable energy investment should be seen as an infrastructure or a private equity investment and the different expectations of returns for these two asset classes is important here.

Higher costs also highlight a particular barrier associated with asymmetric information [101] between the government and the investor, resulting in the need for subsidies or other policy intervention to take this into account. Higher initial costs also link strongly to the need for policy stability over the life time of the investment [102]. While some argue that investment into research and development will lower the costs of renewables [103], this of course ignores the inherent difference in investment profile given that traditional energy assets also include significant operational costs (associated with fuel costs and other operations). Others [104] explore whether the high initial costs actually demand a reform in the power sector and the need for different types of investors, although these changes would create their own barriers.

Alongside these higher costs technical barriers exist [81,99], or at least are perceived to exist [97]. The speed of increase in deployment of renewable infrastructure often means that they are untested at large volumes over long periods of time, leading to the specific performance of individual technologies being less well understood. A particular aspect of immature policy environments, with respect to new technology, is the lack of joined up policy from the research phase of technology development to its large-scale deployment in the field. Often called the 'valley of death', the lack of available investment between high risk venture capital and lower risk private or corporate financing clearly hinders the large-scale growth in climate change solutions [105]. While many of the other barriers identified exist for all types of energy infrastructure, the technology risk associated with renewable infrastructure is specific to each type of technology. However, it is important not to underplay these general barriers as they are often more important [106]. With the relative immaturity of the renewable infrastructure investment market, cash flow uncertainty and unreliable supply chains [107] are often identified as prominent barriers. The lack of track record within the finance market given the lack of a mature investment market is another barrier [108].

While the policy reports mostly focus on the lack of appropriate large scale finance vehicles (fund of funds, public-private partnerships, funds operated by intermediaries with a long term history), one paper also highlighted that financial incentives should be structured to overcome the barrier associated with creating small scale finance vehicles that would be appropriate to attract citizen or community investors in local projects [109]. New types of finance vehicles are also proposed as a solution to the barriers associated with high transaction costs, particularly those associated with decentralised renewable energy [99].

Four barriers identified in the academic literature that were not a clear focus in the policy reports were the issue of grid connectivity, intermittency, public acceptance, and environmental liability. As renewables often only operate under certain conditions (the need for wind for wind turbines or sun for solar photovoltaics), they provide intermittent power and this can often be seen as an inherent barrier to scaling up the deployment of these technologies $[58,110,111]$. Issues associated with grid connection were also highlighted either because of the issue of intermittency, the costs associated with multiple small-scale developments connecting to the grid, or local congestion on the grid where renewable deployments have occurred $[46,50,58,69,80,90]$. Both intermittency and grid connectivity could be classed under technology risk. Associated with the installation of wind farms in particular, the issue of public acceptance was much more strongly emphasised in the academic literature as a potential barrier $[46,58,65,104]$. The risk "arising from liabilities to third parties due to potential environmental damages" $[48,58]$ was also identified as a potential barrier to investment. This barrier is particularly uncertain given that the environmental impact of wind, hydro, or solar infrastructure has 
not been rigorously tested either in the field or in legal processes. The physical risk of damage from severe weather to infrastructure was also mentioned in one paper [58].

Finally, the specific barriers associated with deploying renewable technologies on brownfield sites, particularly the risks associated with those sites being contaminated, was highlighted [112].

\subsection{Testing Barriers Through Implemented Solutions}

A number of the papers identified, while acknowledging the existence of barriers, mainly explore the differences between the effectiveness and efficiency of particular implemented policies (proposed solutions). For example, a number of papers [113-116] examine Feed-in-Tariffs, carbon tax, trading schemes, green certificates [117], energy performance contracts [118], and renewable standards. Indeed, two papers examine implemented policies to propose an optimal mix of policy solutions to enable the scaling up of renewable technology deployment $[119,120]$, while one proposes a real options analysis tool for investors to use based on the different types of uncertainty they are faced with [47].

Many papers explore very specific issues associated with policy design, including exploring the use of price floors in trading schemes [121], showing that voluntary initiatives alone are not sufficient to drive investment [122], and using a Canadian case study to provide guidance on improved public consultation in wind farm development [123]. The particular deployment of a technology or deployment within a country are presented as case studies in some papers $[49,124,125]$. Four papers present different investment vehicles that may provide some of the solution to mobilising capital, including the use of equity indices [126], bonds [127], or the need for a better blending of public and private capital $[128,129]$. Taking a much more theoretical approach, solutions to emission externalities, knowledge spillovers, and capital market imperfections are also explored [130].

In all these solution papers, the barriers to investment that these policies are aimed to address are not always explicitly identified, so while it may be possible to discuss which policy is perceived to be better it is not always possible to confirm that they are actually needed.

A small number of the papers identified focussed on the demand side of energy and, in particular, explored barriers to new technology adoption in the construction sector [131,132], small and medium sized enterprises [133], or energy efficiency [134].

\section{Conclusions}

In this paper we used a set of 31 practice-based policy reports to identify a number of themes and code words associated with barriers to scaling up private sector investment into climate change solutions, predominantly defined as large scale renewable energy infrastructure. These code words were then used on the Web-of-Knowledge database to identify a set of academic papers that included those barriers. In the end, 91 academic papers were reviewed and presented in this paper. We found that this is a growing research field, as demonstrated by the steady increase in published papers and their citations. However, more research is needed to not only identify potential solutions to these barriers, but to also understand the real underlying causes, and the interrelation between them, as otherwise proposed solutions may indeed not tackle the real issue and could lead to unintended outcomes. In addition, as new data becomes increasingly available, the academic community should be prepared to access and analyse this data as this will better inform policy based on real examples of deployed investment.

We of course acknowledge that our search was restricted to those papers published prior to July 2018 and, as outlined in the paper, this is a growing area of focus. Several papers $[135,136]$ have of course been published since, but are not included here. We would recommend that this scoping review is conducted again in a couple of years to map how the research focus has changed. In addition, as we have noted, research is often focused on the developing country context and, in particular, the role of development banks. This would also make a useful subject for a future scoping review and further study as increasing amounts of investment and outcome data are made available. 
In this paper we found that the key barriers were the short-term nature of investors, policy uncertainty, and the lack of appropriate scale in investment opportunities. These barriers are likely due to the immaturity of policy, as well as the immaturity of the renewables investment sector itself. On the one hand, this can be seen as good news as this is something that governments can control and, over time, capacity and expertise will develop. However, it brings with it a challenge in that governments need to be able to design and implement policy that avoids the potential negative consequences of badly developed policy that would lead to further distrust between policy makers and investors. In addition, waiting for the market to mature naturally is not an option. Therefore, there is a need for better engagement between policy, academics, and investors to capture evidence from the early deployment of renewable energy infrastructure and policy to ensure the market develops in as an efficient and effective way as possible. In particular, barriers including technology risk, benchmarking, market liquidity, fossil fuel subsidies, fiduciary duty, and credit rating are less well covered in the academic literature.

In the meantime, the demonstrated and perceived policy uncertainty leads investors to expect higher returns on their investments, which often make the projects themselves unviable or results in an assessed level of risk, which is outside of the investor's decision framework, so they do not even consider making an investment in the first instance. However, as the capital costs of technologies lower, following decades of research and small-scale deployment, then these return expectations may actually be met. In response to increased flows of investment into renewables, governments must respond by learning lessons from these early investments and designing policies in a transparent, simple, and flexible way, such that the trust between investors and policy makers is not further damaged.

In response to our original research question: Academics are widely engaged in exploring the barriers to investments in climate change solutions. However, given the complexity of transitioning to a significantly larger investment market, and the scale of change that is envisaged, we hope this scoping review provides some grounding for this emerging field of research onto which future research can be built.

Author Contributions: The authors contributed the following: conceptualization, S.H. and A.J.; methodology, S.H.; formal analysis, O.J. and S.H.; writing — original draft preparation, S.H. and A.J.; funding acquisition, A.J.

Funding: The financial support of the Economic and Social Research Council for the Centre for the Understanding of Sustainable Prosperity (CUSP) (ESRC grant no: ES/M010163/1) is gratefully acknowledged.

Conflicts of Interest: The authors declare no conflict of interest.

\section{References}

1. International Energy Agency. Climate Policy Uncertainty and Investment Risk. Available online: https: //www.iea.org/publications/freepublications/publication/Climate_Policy_Uncertainty.pdf (accessed on 6 June 2018).

2. IIGCC, INCR, IGCC \& UNEP-FI. Investment-Grade Climate Change Policy: Financing the Transition to the Low-Carbon Economy. Available online: http://www.iigcc.org/publications/publication/proin-scelerisquesuscipit-rhoncus (accessed on 10 May 2018).

3. Climate Policy Initiative. The Challenge of Institutional Investment in Renewable Energy. Available online: https://climatepolicyinitiative.org/publication/the-challenge-of-institutional-investmentin-renewable-energy/ (accessed on 15 June 2018).

4. Aldersgate Group. Towards the New Normal: How to Increase Investments in the UK's Green Infrastructure? Available online: http://www.aldersgategroup.org.uk/events/towards-the-new-normal-how-to-increaseinvestment-in-the-uk-s-green-infrastructure (accessed on 10 May 2018).

5. Institutional Investors Group on Climate Change. Achieving the Investment Plan for Europe's $£ 315$ Billion Ambition: 12 Fixes. Available online: http://www.iigcc.org/files/publication-files/Achieving_EUs_\%E2\%82\% AC315bn_ambition.PDF (accessed on 20 June 2018).

6. EY Climate change. The Investment Perspective. Available online: http://www.ey.com/gl/en/industries/ financial-services/fso-insights-climate-change-the-investment-perspective (accessed on 10 May 2018). 
7. World Bank. Green Infrastructure Finance. Available online: http://documents.worldbank.org/curated/en/ 247041468340183358/pdf/678630PUB0EPI0067902B09780821394885.pdf (accessed on 14 May 2018).

8. Vivid Economics. Financing Green Growth. Available online: http://www.vivideconomics.com/publications/ financing-green-growth (accessed on 14 May 2018).

9. UNEP. Global Trends in Renewable Energy Investment 2018. United Nations Environment, Frankfurt School-UNEP Collaborating Centre \& Bloomberg New Energy Finance. Available online: http://www. greengrowthknowledge.org/resource/global-trends-renewable-energy-investment-report-2018 (accessed on 14 September 2018).

10. GREEN-WIN. Financing the Low-Carbon Transition: Current Landscape and Future Direction. Available online: https://www.green-win-project.eu/resource/financing-low-carbon-transition-current-landscape-andfuture-direction-0 (accessed on 20 June 2018).

11. Wuestenhagen, R.; Menichetti, E. Strategic choices for renewable energy investment: Conceptual framework and opportunities for further research. Energy Policy 2012, 40, 1-10. [CrossRef]

12. Green Investment Bank Commission. Unlocking Investment to Deliver Britain's Low Carbon Future. Available online: https://www.e3g.org/docs/Unlocking_investment_to_deliver_Britains_low_carbon_future_ -_Green_Investment_Bank_Commission_Report_June_2010.pdf (accessed on 15 May 2018).

13. G20 Green Finance Study Group. G20 Green Finance Synthesis Report. Available online: http://unepinquiry. org/g20greenfinancerepositoryeng/ (accessed on 5 June 2018).

14. Jones, A. Perceived barriers and policy solutions in clean energy infrastructure investment. J. Clean. Prod. 2015, 104, 297. [CrossRef]

15. Linnenluecke, M.K.; Smith, T.; McKnight, B. Environmental finance: A research agenda for interdisciplinary finance research. Econ. Model. 2016, 59, 124-130. [CrossRef]

16. Taskforce on Climate related Financial Disclosures. Final Report: Recommendations of the Task Force on Climate Related Financial Disclosures; Financial Stability Board: Basel, Switzerland, 2017.

17. Diaz-Rainey, I.; Robertson, B.; Wilson, C. Stranded research? Leading finance journals are silent on climate change. Clim. Chang. 2017, 143, 243-260.

18. Peterson, J.; Pearce, P.; Ferguson, L.; Langford, L. Understanding scoping reviews: Definition, purpose and process. J. Am. Assoc. Nurse Pract. 2017, 29, 12-16. [CrossRef] [PubMed]

19. British Banking Association. Financing the UK's Infrastructure Needs. Available online: https://www.bba. org.uk/news/reports/financing-the-uks-infrastructure-needs/\#.WxEPpmaWwdU (accessed on 1 June 2018).

20. E3G (2016) A Sustainable Finance Plan for the European Union. Available online: https://www.e3g.org/docs/ A_Sustainable_Finance_Plan_for_the_EU.pdf (accessed on 19 June 2018).

21. EU High Level Expert Group On Sustainable Finance. Financing a Sustainable European Economy. Available online: https://ec.europa.eu/info/sites/info/files/180131-sustainable-finance-final-report_en.pdf (accessed on 30 May 2018).

22. European Commission. Financing Sustainability. Triggering Investments for the Clean Economy. Available online: https://ec.europa.eu/epsc/publications/strategic-notes/financing-sustainability_en (accessed on 10 May 2018).

23. Green Finance Initiative The Renewable Energy Infrastructure Investment Opportunity for UK Pension Funds. Available online: http://greenfinanceinitiative.org/wp-content/uploads/2017/11/Final-Report-14.11.2017.pdf (accessed on 14 May 2018).

24. Green Finance Initiative. Fifteen Steps to Green Finance. Available online: http://greenfinanceinitiative.org/ fifteen-steps-to-green-finance/ (accessed on 10 May 2018).

25. Green Finance Taskforce. Accelerating Green Finance. Available online: https:/www.gov.uk/government/ publications/accelerating-green-finance-green-finance-taskforce-report (accessed on 14 May 2018).

26. IFC. Mobilizing Public and Private Funds for Inclusive Green Growth Investment in Developing Countries. Available online: https://openknowledge.worldbank.org/handle/10986/26450 (accessed on 14 May 2018).

27. International Centre for Trade and Sustainable Development. Breaking down The Barriers to Clean Energy Trade and Investment. Available online: https://www.ictsd.org/bridges-news/biores/news/breaking-downthe-barriers-to-clean-energy-trade-and-investment (accessed on 14 May 2018).

28. IRENA. Unlocking Renewable Energy Investment: The Role of Risk Mitigation and Structured Finance. Available online: http:/www.irena.org/publications/2016/Jun/Unlocking-Renewable-Energy-InvestmentThe-role-of-risk-mitigation-and-structured-finance (accessed on 14 May 2018). 
29. Mercer. Investing in a Time of Climate Change. Available online: https://www.mercer.com/content/dam/ mercer/attachments/global/investments/mercer-climate-change-report-2015.pdf (accessed on 14 May 2018).

30. Organisation for Economic Co-operation and Development (OECD). The Role of Pension Funds in Financing Green Growth Initiatives. Available online: http://www.oecd.org/finance/private-pensions/49016671.pdf (accessed on 12 June 2018).

31. Organisation for Economic Co-operation and Development (OECD). Towards a Green Investment Policy Framework: The Case of Low-Carbon, Climate-Resilient Infrastructure. Available online: https://www.oecdilibrary.org/content/paper/5k8zth7s6s6d-en (accessed on 19 June 2018).

32. Organisation for Economic Co-operation and Development (OECD). Long-Term Investors and Green Infrastructure. Available online: http://www.oecd.org/env/cc/Investors\%20in\%20Green\%20Infrastructure\% 20brochure\%20(f)\%20\%5Blr\%5D.pdf (accessed on 14 June 2018).

33. Organisation for Economic Co-operation and Development (OECD). Institutional Investors and Green Infrastructure Investments. Available online: https://www.oecd-ilibrary.org/docserver/5k3xr8k6jb0n-en. pdf?expires=1529066539\&id=id\&accname=guest\&checksum=37EA0A186EA86CFEF8496874A8E14AFD (accessed on 13 June 2018).

34. Organisation for Economic Co-operation and Development (OECD). Public Financial Institutions and the Low-Carbon Transitions: Five Case Studies on Low-Carbon Infrastructure and Project Investment, OECD Environment. Available online: http://dx.doi.org/10.1787/5jxt3rhpgn9t-en (accessed on 14 May 2018).

35. Organisation for Economic Co-operation and Development (OECD). Mobilising Private Investment in Clean-Energy Infrastructure. Available online: https://www.oecd.org/investment/investment-policy/Privateinvestment-in-clean-energy-infrastructure.pdf (accessed on 14 June 2018).

36. Organisation for Economic Co-operation and Development (OECD). Overcoming Barriers to International Investment in Clean Energy. Available online: http://www.oecd.org/fr/publications/overcoming-barriers-tointernational-investment-in-clean-energy-9789264227064-en.htm (accessed on 12 June 2018).

37. Organisation for Economic Co-operation and Development (OECD). Progress Report on Approaches to Mobilising Institutional Investment for Green Infrastructure. Available online: http://unepinquiry.org/wp-content/uploads/2016/09/11_Progress_Report_on_Approaches_to_ Mobilising_Institutional_Investment_for_Green_Infrastructure.pdf (accessed on 6 June 2018).

38. UNEP. The Financial System We Need: Aligning Financial System with Sustainable Development. Available online: http://unepinquiry.org/publication/inquiry-global-report-the-financial-system-we-need/ (accessed on 14 May 2018).

39. Corbin, J.; Strauss, A. Grounded theory research: Procedures, canons, and evaluative criteria. Qual. Sociol. 1990, 13, 3-21. [CrossRef]

40. Arksey, H.; O'Malley, L. Scoping studies: Towards a methodological framework. Int. J. Soc. Res. Methodol. 2005, 8, 19-32. [CrossRef]

41. Gale, R. Environment and Development: Attitudinal Impediments to Policy Integration. Environ. Conserv. 1992, 18, 228-236. [CrossRef]

42. Gale, R. Environment and Economy: The Policy Models of Development. Environ. Behav. 1992, $24,723-737$. [CrossRef]

43. Wells, V.; Greenwell, F.; Covey, J.; Rosenthal, H.E.S.; Adcock, M.; Gregory-Smith, D. An exploratory investigation of barriers and enablers affecting investment in renewable companies and technologies in the UK. Interface Focus 2013, 3, 20120039. [CrossRef]

44. Sandberg, J. Socially Responsible Investment and Fiduciary Duty: Putting the Freshfields Report into Perspective. J. Bus. Ethics 2011, 101, 143-162. [CrossRef]

45. Richardson, B.J. Do the Fiduciary Duties of Pension Funds Hinder Socially Responsible Investment? Bank. Financ. Law Rev. 2007, 22, 145-201.

46. Klessmann, C.; Held, A.; Rathmann, M.; Ragwitz, M. Status and perspectives of renewable energy policy and deployment in the European Union-What is needed to reach the 2020 targets? Energy Policy 2011, 39, 7637-7657. [CrossRef]

47. Fuss, S.; Szolgayova, J.; Khabarov, N.; Obersteiner, M. Renewables and climate change mitigation: Irreversible energy investment under uncertainty and portfolio effects. Energy Policy 2012, 40, 59-68. [CrossRef]

48. Soderholm, P.; Ek, K.; Pettersson, M. Wind power development in Sweden: Global policies and local obstacles. Renew. Sustain. Energy Rev. 2007, 11, 365-400. [CrossRef] 
49. Sarasa-Maestro, C.J.; Dufo-Lopez, R.; Bernal-Agustin, J.L. Photovoltaic remuneration policies in the European Union. Energy Policy 2013, 55, 317-328. [CrossRef]

50. Soshinskaya, M.; Crijns-Graus, W.H.J.; Guerrero, J.M.; Vasquez, J.C. Microgrids: Experiences, barriers and success factors. Renew. Sustain. Energy Rev. 2014, 40, 659-672. [CrossRef]

51. Barradale, M.J. Impact of public policy uncertainty on renewable energy investment: Wind power and the production tax credit. Energy Policy 2010, 38, 7698-7709. [CrossRef]

52. Stokes, L.C. The politics of renewable energy policies: The case of feed-in tariffs in Ontario, Canada. Energy Policy 2013, 56, 490-500. [CrossRef]

53. Vogt-Schilb, A.; Hallegatte, S. Climate policies and nationally determined contributions: Reconciling the needed ambition with the political economy. Wires Energy Environ. 2017, 6, e256. [CrossRef]

54. Masi, D.; Kumar, V.; Garza-Reyes, J.A.; Godsell, J. Towards a more circular economy: Exploring the awareness, practices, and barriers from a focal firm perspective. Prod. Plan. Control 2018, 29, 539-550. [CrossRef]

55. Hu, J.; Harmsen, R.; Crijns-Graus, W.; Worrell, E. Barriers to investment in utility-scale variable renewable electricity (VRE) generation projects. Renew. Energy 2018, 121, 730-744. [CrossRef]

56. Mazzucato, M.; Semieniuk, G. Financing renewable energy: Who is financing what and why it matters. Technol. Forecast. Soc. Chang. 2018, 127, 8-22. [CrossRef]

57. Schmidt, T.S.; Battke, B.; Grosspietsch, D.; Hoffmann, V.H. Do deployment policies pick technologies by (not) picking applications?-A simulation of investment decisions in technologies with multiple applications. Res. Policy 2016, 45, 1965-1983. [CrossRef]

58. Gatzert, N.; Kosub, T. Risks and risk management of renewable energy projects: The case of onshore and offshore wind parks. Renew. Sustain. Energy Rev. 2016, 60, 982-998. [CrossRef]

59. Gatzert, N.; Kosub, T. The Impact of European Initiatives on the Treatment of Insurers' Infrastructure Investments Under Solvency II. Geneva Pap. Risk Insur. Issues Pract. 2017, 42, 708-731. [CrossRef]

60. Polzin, F. Mobilizing private finance for low-carbon innovation-A systematic review of barriers and solutions. Renew. Sustain. Energy Rev. 2017, 77, 525-535. [CrossRef]

61. Hu, J.; Harmsen, R.; Crijns-Graus, W.; Worrell, E.; van den Broek, M. Identifying barriers to large-scale integration of variable renewable electricity into the electricity market: A literature review of market design. Renew. Sustain. Energy Rev. 2018, 81, 2181-2915. [CrossRef]

62. Hall, S.; Foxon, T.J.; Bolton, R. Investing in low-carbon transitions: Energy finance as an adaptive market. Clim. Policy 2017, 17, 280-298. [CrossRef]

63. Richards, G.; Noble, B.; Belcher, K. Barriers to renewable energy development: A case study of large-scale wind energy in Saskatchewan, Canada. Energy Policy 2012, 42, 691-698. [CrossRef]

64. Bellantuono, G. The misguided quest for regulatory stability in the renewable energy sector. J. World Energy Law Bus. 2017, 10, 274-292. [CrossRef]

65. Byrnes, L.; Brown, C.; Foster, J.; Wagner, L.D. Australian renewable energy policy: Barriers and challenges. Renew. Energy 2013, 60,711-721. [CrossRef]

66. del Rio, P.; Tarancon, M.; Penasco, C. The determinants of support levels for wind energy in the European Union. An econometric study. Mitig. Adapt. Strateg. Glob. Chang. 2014, 19, 391-410. [CrossRef]

67. Del Rio, P.; Tarancon, M. Analysing the determinants of on-shore wind capacity additions in the EU: An econometric study. Appl. Energy 2012, 95, 12-21. [CrossRef]

68. Gatzert, N.; Vogl, N. Evaluating investments in renewable energy under policy risks. Energy Policy 2016, 95, 238-252. [CrossRef]

69. Gonzalez, J.S.; Lacal-Arantegui, R. A review of regulatory framework for wind energy in European Union countries: Current state and expected developments. Renew. Sustain. Energy Rev. 2016, 56, 588-602. [CrossRef]

70. Karneyeva, Y.; Wuestenhagen, R. Solar feed-in tariffs in a post-grid parity world: The role of risk, investor diversity and business models. Energy Policy 2017, 106, 445-456. [CrossRef]

71. Boomsma, T.K.; Linnerud, K. Market and policy risk under different renewable electricity support schemes. Energy 2015, 89, 435-448. [CrossRef]

72. Chronopoulos, M.; Hagspiel, V.; Fleten, S. Stepwise Green Investment under Policy Uncertainty. Energy J. 2016, 37, 87-108. [CrossRef]

73. Criscuolo, C.; Menon, C. Environmental policies and risk finance in the green sector: Cross-country evidence. Energy Policy 2015, 83, 38-56. [CrossRef] 
74. Chen, L.; Kettunen, J. Is certainty in carbon policy better than uncertainty? Eur. J. Oper. Res. 2017, 258, 230-243. [CrossRef]

75. Holburn, G.; Lui, K.; Morand, C. Policy Risk and Private Investment in Ontario's Wind Power Sector. Can. Public Policy 2010, 6, 465-486.

76. Boute, A. The Quest for Regulatory Stability in the EU Energy Market: An Analysis through the Prism of Legal Certainty. Eur. Law Rev. 2012, 37, 675-692. [CrossRef]

77. Nelson, T.; Nelson, J.; Ariyaratnam, J.; Camroux, S. An analysis of Australia's large scale renewable energy target: Restoring market confidence. Energy Policy 2013, 62, 386-400. [CrossRef]

78. Kann, S. Overcoming barriers to wind project finance in Australia. Energy Policy 2009, 37, 3139-3148. [CrossRef]

79. Bode, S.; Michaelowa, A. Avoiding perverse effects of baseline and investment additionality determination in the case of renewable energy projects. Energy Policy 2003, 31, 505-517. [CrossRef]

80. Lozano, R.; Reid, A. Socially responsible or reprehensible? Investors, electricity utility companies, and transformative change in Europe. Energy Res. Soc. Sci. 2018, 37, 37-43. [CrossRef]

81. De Cian, E.; Massimo, T. Mitigation Portfolio and Policy Instruments When Hedging Against Climate Policy and Technology Uncertainty. Environ. Model. Assess. 2012, 17, 123-136. [CrossRef]

82. Li, M. Analysis of the Financing of Hydropower Projects. In Proceedings of the CRIOCM2009 International Symposium on Advancement of Construction Management and Real Estate, Nanjing, China, 29 October 2009.

83. Linnerud, K.; Holden, E. Investment barriers under a renewable-electricity support scheme: Differences across investor types. Energy 2015, 87, 699-709. [CrossRef]

84. Linnerud, K.; Simonsen, M. Swedish-Norwegian tradable green certificates: Scheme design flaws and perceived investment barriers. Energy Policy 2017, 106, 560-578. [CrossRef]

85. Salm, S.; Hille, S.L.; Wustenhagen, R. What are retail investors' risk-return preferences towards renewable energy projects? A choice experiment in Germany. Energy Policy 2016, 97, 310-320. [CrossRef]

86. Espinoza, O.; Mallo, M.F.L.; Weitzenkamp, M. Overcoming barriers to biomass cogeneration in US wood products industry. Wood Fiber Sci. 2015, 47, 295-312.

87. Junginger, M.; Schouwenberg, P.P.; Nikolaisen, L.; Andrade, O. Drivers and Barriers for Bioenergy Trade. In International Bioenergy Trade Lecture Notes in Energy; Junginger, M., Goh, C., Faaij, A., Eds.; Springer: Dordrecht, The Netherlands, 2014; p. 17.

88. Martinot, E. Renewable energy in Russia: Markets, development and technology transfer. Renew. Sustain. Energy Rev. 1999, 3, 49-75. [CrossRef]

89. Pfeifer, S.; Sullivan, R. Public policy, institutional investors and climate change: A UK case-study. Clim. Chang. 2008, 89, 245-262. [CrossRef]

90. Ruggiero, S.; Varho, V.; Rikkonen, P. Transition to distributed energy generation in Finland: Prospects and barriers. Energy Policy 2015, 86, 433-443. [CrossRef]

91. Gatzert, N.; Kosub, T. Determinants of policy risks of renewable energy investments International. J. Energy Sect. Manag. 2017, 11, 28-45. [CrossRef]

92. Kuik, O.; Fuss, S. Renewables in the Energy Market: A Financial-Technological Analysis Considering Risk and Policy Options. In Financial Aspects in Energy; Dorsman, A., Westerman, W., Karan, M., Arslan, Ö., Eds.; Springer: Berlin, Germany, 2011; pp. 33-50.

93. Michaelowa, A.; Allen, M.; Sha, F. Policy instruments for limiting global temperature rise to 1.5 degrees C can humanity rise to the challenge? Clim. Policy 2018, 18, 275-286. [CrossRef]

94. Koch, H.J. Policies for Financing Renewables. In READy: Renewable Energy Action on Deployment-Policies for Accelerated Deployment of Renewable Energy; de Vos, R., Ed.; Elsevier: Utrecht, The Netherlands, 2013.

95. Breitschopf, B.; Pudlik, M. Basel Iii and Solvency Ii: Are the Risk Margins for Investments in Pv and Wind Adequate? Energy Environ. 2013, 24, 171-194. [CrossRef]

96. Masini, A.; Menichetti, E. Investment decisions in the renewable energy field: An analysis of main determinants. In Proceedings of the PICMET 2010 Technology Management for Global Economic Growth, Phuket, Thailand, 18-22 July 2010.

97. Fung, C.C.; Tang, S.C.; Xu, Z.; Wong, K.P. Comparing Renewable Energy policies in four countries \& overcoming consumers' adoption barriers with REIS. In Proceedings of the IEEE Power and Energy Society General Meeting, PES, Vancouver, BC, Canada, 21-25 July 2013. 
98. Geddes, A.; Schmidt, T.S.; Steffen, B. The multiple roles of state investment banks in low-carbon energy finance: An analysis of Australia, the UK and Germany. Energy Policy 2018, 115, 158-170. [CrossRef]

99. Arnold, U.; Yildiz, O. Economic risk analysis of decentralized renewable energy infrastructures-A Monte Carlo Simulation approach. Renew. Energy 2015, 77, 227-239. [CrossRef]

100. Aguilar, F.X.; Cai, Z. Exploratory analysis of prospects for renewable energy private investment in the U.S. Energy Econ. 2010, 32, 1245-1252. [CrossRef]

101. Chen, W.; Yin, H. Optimal subsidy in promoting distributed renewable energy generation based on policy benefit. Clean Technol. Environ. Policy 2017, 19, 225-233. [CrossRef]

102. Leete, S.; $\mathrm{Xu}, \mathrm{J} . ;$ Wheeler, D. Investment barriers and incentives for marine renewable energy in the UK: An analysis of investor preferences. Energy Policy 2013, 60, 866-875. [CrossRef]

103. Esmaieli, M.; Ahmadian, M. The effect of research and development incentive on wind power investment, a system dynamics approach. Renew. Energy 2018, 126, 765-773. [CrossRef]

104. Matthes, F.C. Energy transition in Germany: A case study on a policy-driven structural change of the energy system. Evol. Inst. Econ. Rev. 2017, 14, 141-169. [CrossRef]

105. Yanosek, K. Policies for Financing the Energy Transition. Daedalus 2012, 141, 94-104. [CrossRef]

106. Granoff, I.; Hogarth, J.R.; Miller, A. Nested barriers to low-carbon infrastructure investment. Nat. Clim. Chang. 2016, 6, 1065-1071. [CrossRef]

107. Kayser, D. Solar photovoltaic projects in China: High investment risks and the need for institutional response. Appl. Energy 2016, 174, 144-152. [CrossRef]

108. Finon, D. The transition of the electricity system towards decarbonization: The need for change in the market regime. Clim. Policy 2013, 13, 130-145. [CrossRef]

109. Curtin, J.; McInerney, C.; Johannsdottir, L. How can financial incentives promote local ownership of onshore wind and solar projects? Case study evidence from Germany, Denmark, the UK and Ontario. Local Econ. 2018, 33, 40-62. [CrossRef]

110. Aflaki, S.; Netessine, S. Strategic Investment in Renewable Energy Sources: The Effect of Supply Intermittency. Manuf. Serv. Oper. Manag. 2017, 19, 489-507. [CrossRef]

111. Alishahi, E.; Moghaddam, M.P.; Sheikh-El-Eslami, M.K. A system dynamics approach for investigating impacts of incentive mechanisms on wind power investment. Renew. Energy 2012, 37, 310-317. [CrossRef]

112. Spiess, T.; De Sousa, C. Barriers to Renewable Energy Development on Brownfields. J. Environ. Policy Plan. 2016, 18, 507-534. [CrossRef]

113. Abolhosseini, S.; Heshmati, A. The main support mechanisms to finance renewable energy development. Renew. Sustain. Energy Rev. 2014, 40, 876-885. [CrossRef]

114. Deng, Y.; Guo, W. A Review of Investment, Financing and Policies Support Mechanisms for Renewable Energy Development. In Proceedings of the Tenth International Conference on Management Science and Engineering Management, Singapore, 24 August 2016; p. 502.

115. Garcia, A.; Alzate, J.M.; Barrera, J. Regulatory design and incentives for renewable energy. J. Regul. Econ. 2012, 41, 315-336. [CrossRef]

116. Kitzing, L. Risk implications of renewable support instruments: Comparative analysis of feed-in tariffs and premiums using a mean-variance approach. Energy 2014, 64, 495-505. [CrossRef]

117. Linnerud, K.; Andersson, A.M.; Fleten, S. Investment timing under uncertain renewable energy policy: An empirical study of small hydropower projects. Energy 2014, 78, 154-164. [CrossRef]

118. Tsoutsos, T.; Tournaki, S.; Farmaki, E.; Sonvilla, P.; Lensing, P.; Bartnicki, J.; Cobos, A.; Biscan, M. Benchmarking Framework to Encourage Energy Efficiency Investments in South Europe. The Trust EPC South Approach. Procedia Environ. Sci. 2017, 38, 413-419. [CrossRef]

119. Polzin, F.; Migendt, M.; Taeube, F.A.; von Flotow, P. Public policy influence on renewable energy investments-A panel data study across OECD countries. Energy Policy 2015, 80, 98-111. [CrossRef]

120. Rasouli, M.; Teneketzis, D. A methodology for Generation Expansion Planning for renewable energy economies. In Proceedings of the 2016 IEEE 55th Conference on Decision and Control (CDC), Las Vegas, NV, USA, 12-14 December 2016; pp. 1556-1563.

121. Bodnar, P.; Ott, C.; Edwards, R.; Hoch, S.; McGlynn, E.F.; Wagner, G. Underwriting $1.5{ }^{\circ} \mathrm{C}$ : Competitive approaches to financing accelerated climate change mitigation. Clim. Policy 2017, 18, 368-382. [CrossRef]

122. Gillenwater, M. Probabilistic decision model of wind power investment and influence of green power market. Energy Policy 2013, 63, 1111-1125. [CrossRef] 
123. Jami, A.A.N.; Walsh, P.R. The role of public participation in identifying stakeholder synergies in wind power project development: The case study of Ontario, Canada. Renew. Energy 2014, 68, 194-202. [CrossRef]

124. Gisler, T.; Capezzali, M.; Guittet, M.; Burkhard, R.; Favrat, D. Evaluation and recommendation of a subsidy instrument for new large hydropower plants, use case of Switzerland. Sustain. Energy Technol. Assess. 2018, 26, 6-16. [CrossRef]

125. Montes, G.; Prados Martin, E.; Ordonez Garcia, J. The current situation of wind energy in Spain. Renew. Sustain. Energy Rev. 2007, 11, 467-481. [CrossRef]

126. Rezec, M.; Scholtens, B. Financing energy transformation: The role of renewable energy equity indices. Int. J. Green Energy 2017, 14, 368-378. [CrossRef]

127. Lee, C.W.; Zhong, J. Financing and risk management of renewable energy projects with a hybrid bond. Renew. Energy 2015, 75, 779-787. [CrossRef]

128. Eichhammer, W.; Ragwitz, M.; Schlomann, B. Financing Instruments to Promote Energy Efficiency and Renewables in Times of Tight Public Budgets. Energy Environ. 2013, 24, 1-26. [CrossRef]

129. Owen, R.; Brennan, G.; Lyon, F. Enabling investment for the transition to a low carbon economy: Government policy to finance early stage green innovation. Curr. Opin. Environ. Sustain. 2018, 31, 137-145. [CrossRef]

130. Kempa, K.; Moslener, U. Climate policy with the chequebook-An economic analysis of climate investment support. Econ. Energy Environ. Policy 2017, 6, 219. [CrossRef]

131. Aiello, S. Addressing Financial Objections to Sustainable Design and Construction. J. Green Build. Fall 2010 2010, 5, 67-77. [CrossRef]

132. Bjorneboe, M.G.; Svendsen, S.; Heller, A. Initiatives for the energy renovation of single-family houses in Denmark evaluated on the basis of barriers and motivators. Energy Build. 2018, 167, 347-358. [CrossRef]

133. Ghisetti, C.; Mancinelli, S.; Mazzanti, M.; Zoli, M. Financial barriers and environmental innovations: Evidence from EU manufacturing firms. Clim. Policy 2017, 17, 131-147. [CrossRef]

134. Haeckel, B.; Pfosser, S.; Traenkler, T. Explaining the energy efficiency gap-Expected Utility Theory versus Cumulative Prospect Theory. Energy Policy 2017, 111, 414-426. [CrossRef]

135. Campiglio, E.; Dafermos, Y.; Monnin, P.; Ryan-Collins, J.; Schotten, G.; Tanaka, M. Climate change challenges for central banks and financial regulators. Nat. Clim. Chang. 2018, 8, 462-468. [CrossRef]

136. Egli, F.; Steffen, B.; Schmidt, T.S. A dynamic analysis of financing conditions for renewable energy technologies. Nat. Energy 2018, 3, 1084-1092. [CrossRef]

(C) 2019 by the authors. Licensee MDPI, Basel, Switzerland. This article is an open access article distributed under the terms and conditions of the Creative Commons Attribution (CC BY) license (http://creativecommons.org/licenses/by/4.0/). 